\title{
Yield and nutritive value of the silage of corn intercropped with tropical perennial grasses
}

\author{
Nídia Raquel Costa( ${ }^{(1)}$, Marcelo Andreotti(2), Carlos Alexandre Costa Crusciol(1), César Gustavo da Rocha Lima( ${ }^{(3)}$, \\ André Michel de Castilhos $^{(4)}$, Daniel Martins de Souza( ${ }^{(4)}$, Carolina dos Santos Batista Bonini ${ }^{(5)}$ \\ and Cristiano Magalhães Pariz ${ }^{(4)}$
}

\begin{abstract}
(1)Universidade Estadual Paulista Júlio de Mesquita Filho (Unesp), Faculdade de Ciências Agronômicas, Departamento de Produção e Melhoramento Vegetal, Fazenda Lageado, Rua José Barbosa de Barros, no 1.780, CEP 18610-307 Botucatu, SP, Brazil. E-mail: nidiarcosta@gmail.com, crusciol@fca.unesp.br (2)Unesp, Faculdade de Engenharia, Departamento de Fitossanidade, Engenharia Rural e Solos, Avenida Brasil, no 56, Centro, CEP 15385-000 Ilha Solteira, SP, Brazil. E-mail: dreotti@agr.feis.unesp.br (3)Unesp, Faculdade de Engenharia, Departamento de Engenharia Civil, Avenida Brasil, no 56, Centro, CEP 15385-000 Ilha Solteira, SP, Brazil. E-mail: cesarlima@dec.feis.unesp.br (4)Unesp, Faculdade de Medicina Veterinária e Zootecnia, Departamento de Produção Animal, Rua Prof. Doutor Walter Mauricio Correa, s/no, Caixa Postal 560, CEP 18618-681 Botucatu, SP, Brazil. E-mail: michel@fmvz.unesp.br, souzadm.zoo@gmail.com, cmpzoo@gmail.com ${ }^{(5)}$ Unesp, Faculdade de Ciências Agrárias e Tecnológicas, Rodovia Comandante João Ribeiro de Barros, Km 651, Bairro das Antas, CEP 17900-000 Dracena, SP, Brazil. E-mail: cbbonini@gmail.com
\end{abstract}

Abstract - The objective of this work was to compare the yield and nutritive value of the silage of corn intercropped with palisade grass (Urochloa brizantha 'Marandu') or guinea grass (Megathyrsus maximus 'Tanzânia') with those of the silage of monocropped corn, as well as to evaluate the pasture established in the intercropping systems during two growing seasons (2010-2011 and 2011-2012), in low-altitude Brazilian Cerrado. The treatments consisted of three cropping systems: monocropped corn, corn intercropped with palisade grass, and corn intercropped with guinea grass, with four replicates. Intercropping decreased corn forage dry matter yield for silage; however, due to the addition of grass, total dry matter yield (corn + grass) was similar between treatments. Intercropping also did not negatively affect corn production components and morphological characteristics. The cropping systems provided silages with good nutritive values, and the inclusion of tropical forages increased the silage fiber contents. Intercropping corn with tropical perennial grasses is a viable option for producing large quantities of silage with good nutritive value. The forage yield (silage + pasture) of these intercropping systems is similar to that of monocropped corn in tropical regions and has the advantage of providing a pasture in the off-season.

Index terms: Megathyrsus maximus, Urochloa brizantha, Zea mays, Brazilian Cerrado, intercropped system.

\section{Produtividade e valor nutritivo da silagem de milho em consórcio com gramíneas perenes tropicais}

Resumo - O objetivo deste trabalho foi comparar a produtividade e o valor nutritivo da silagem de milho em consórcio com capim-marandu (Urochloa brizantha 'Marandu') ou capim-tanzânia (Megathyrsus maximus 'Tanzânia') aos da silagem de milho em monocultivo, bem como avaliar a pastagem estabelecida nos sistemas consorciados durante duas estações de cultivo (2010-2011 e 2011-2012), em Cerrado brasileiro de baixa altitude. Os tratamentos consistiram de três sistemas de cultivo: milho em monocultivo, milho em consórcio com capim-marandu e milho em consórcio com capim-tanzânia, em quatro repetições. O cultivo consorciado diminuiu a produtividade de massa seca de forragem de milho para silagem; porém, devido à adição do capim, a produtividade total de massa seca (milho + capim) foi similar entre os tratamentos. O consórcio também não afetou negativamente os componentes de produção e as características morfológicas do milho. Os sistemas de cultivo produziram silagens com bons valores nutricionais, e a inclusão de forrageiras tropicais aumentou os teores de fibra na silagem. O consórcio do milho com gramíneas perenes tropicais é viável para a produção de grandes quantidades de silagem com boa qualidade nutricional. A produção de forragem (silagem + pastagem) desses sistemas consorciados é similar à do milho em monocultivo em regiões tropicais e tem a vantagem de proporcionar pastagem na entressafra.

Termos para indexação: Megathyrsus maximus, Urochloa brizantha, Zea mays, Cerrado, sistema consorciado.

\section{Introduction}

Corn (Zea mays L.) silage is used extensively as a ruminant feedstuff and is considered to have consistent nutritional qualities and a high energy value (Khan et al., 2015; Lim et al., 2015). It is the most widely used by farmers in Brazil, representing more than $80 \%$ of overall silage production in the country (Bernardes 
\& Rêgo, 2014). According to these same authors, the ensiling process is the main method of preserving forage in countries with hot and humid climates. This practice aims to circumvent adverse weather conditions and to provide animals with good quality feed, which assists in livestock maintenance during the dry season.

Besides the production of silage using monocropped corn, the combination of this annual crop with tropical forage grasses has been used to increase total dry matter production during the year (Leonel et al., 2009; Borghi et al., 2013) and to recover degraded pastures (Mateus et al., 2016). Therefore, in the notillage system (NTS), tropical forages, such as palisade grass [Urochloa brizantha (A.Rich.) R.D.Webster 'Marandu' (Syn. Brachiaria brizantha)] and guinea grass [Megathyrsus maximus (Jacq.) B.K.Simon \& S.W.L.Jacobs 'Tanzânia'], can be intercropped with cash crops, including corn, sorghum [Sorghum bicolor (L.) Moench], and soybean [Glycine max (L.) Merr.], aiming to produce grain or silage, with subsequent production of forage for animal feed from autumn to spring (Costa et al., 2012; Crusciol et al., 2014, 2016; Mateus et al., 2016). The forage produced can be used for grazing, cut for silage, cut for silage followed by grazing, and cut for hay in the integrated crop-livestock system (ICLS), enabling animal feeding in a pasture, semi-feedlot, or feedlot (Pariz et al., 2016), and can also be used for straw production, giving continuity to the NTS (Mendonça et al., 2015; Pereira et al., 2016).

Most cattle ranching in Brazil is predominantly pasture-based in extensive areas, such as in the Brazilian Cerrado. This region is one of the main agricultural areas in the world due to its soil and climate characteristics. The Cerrado biome covers approximately 205 million hectares and is mostly suitable for growing annual cash crops (Sano et al., 2008). However, these types of crops are rarely cultivated in the low-altitude areas of the Cerrado, which, instead, are dominated by degraded pastures, with very low forage supply in the off-season because of climate conditions (Mateus et al., 2016). In Brazil, approximately 80 million hectares of pastures are degraded, i.e., have low forage production (Janusckiewicz et al., 2015).

Therefore, in the country and in several regions worldwide, there is the need to restore degraded areas, reduce production costs, and intensify agricultural activity throughout the year. Satisfactory results have been obtained by using intercropped crops and ICLS under NTS (Bell \& Moore, 2012; Costa et al. 2012; Crusciol et al., 2013). The practice of combining intercropped crops under NTS is one of the best alternatives for maintaining sustainability in tropical agricultural systems and can result in higher revenues for farmers, due to their productive, economic, and environmental benefits (Costa et al., 2015a, 2015b; Crusciol et al., 2016).

Researchers and farmers have observed several advantages of this management system that can benefit both of the crops combined (Costa et al., 2012; Borghi et al., 2013; Crusciol et al., 2016). In intercropping systems, it is possible to produce annual grain crops, silage and forage for animal grazing, which improves the carrying capacity of the pastures and increases food production without requiring additional land (Borghi et al., 2013).

Most studies on intercropping have assessed corn yields and grass production during the off-season, aiming to better manage species intercropping in order to decrease the competition between crops and increase productivity. However, works that determine the nutritive value of silage and pasture in these systems are scarce, especially in tropical regions. Therefore, more information about the new practices for silage production and grazed pastures from intercropping systems is necessary to consolidate the technologies that are used in these production systems. It is believed that intercropping systems do not reduce the yield and nutritive value of corn-based silage, compared with monocrops, and that intercropping systems could provide increased production of forage (silage + pasture) during all the year in tropical regions, characterized by a dry winter.

The objective of this work was to compare the yield and nutritive value of the silage of corn intercropped with palisade grass or guinea grass with those of the silage of monocropped corn, as well as to evaluate the established pasture in the intercropping systems during two growing seasons (2010-2011 and 2011-2012), in low-altitude Brazilian Cerrado.

\section{Materials and Methods}

The experiment was conducted in the municipality of Selvíria, in the state of Mato Grosso do Sul, Brazil $\left(20^{\circ} 18^{\prime} \mathrm{S}, 51^{\circ} 22^{\prime} \mathrm{W}\right.$, at $370 \mathrm{~m}$ above sea level) over two 
consecutive growing seasons (2010-2011 and 20112012). The soil in the study region is classified as a Typic Haplorthox - Latossolo Vermelho distroférrico (Santos et al., 2006) - containing 482, 140, and $378 \mathrm{~g} \mathrm{~kg}^{-1}$ clay, silt, and sand, respectively. According to Köppen-Geiger, the climate of the region is classified as Aw and is characterized as tropical and humid, with a rainy summer and a dry winter. The annual maximum and minimum temperatures are 31.3 and $18.4^{\circ} \mathrm{C}$, respectively; the annual average mean temperature is $24.8^{\circ} \mathrm{C}$; and the annual average rainfall is $1,309.4 \mathrm{~mm}$. Monthly rainfall and the maximum and minimum temperatures during the experimental period are shown in Table 1.

Soil chemical characteristics in the $0.0-0.20-\mathrm{m}$ layer were determined according to Raij et al. (2001). Before the beginning of the experiment, soil analyses indicated: $\mathrm{pH} 5.1 ; 25 \mathrm{~g} \mathrm{dm}^{-3}$ total soil organic matter; $33 \mathrm{mg} \mathrm{kg}^{-1} \mathrm{P}$ (resin); 4.1, 28, 16, and 29 mmol $_{\mathrm{c}} \mathrm{kg}^{-1}$ exchangeable $\mathrm{K}, \mathrm{Ca}, \mathrm{Mg}$, and total acidity at $\mathrm{pH} 7.0$ $(\mathrm{H}+\mathrm{Al})$, respectively; and base saturation of $481 \mathrm{~g} \mathrm{~kg}^{-1}$.

Before October 2010, annual and semi-evergreen crops, including corn, soybean, sorghum, dwarf pigeon pea [Cajanus cajan (L.) Millsp.], palisade grass, bean (Phaseolus vulgaris L.), and rice (Oryza sativa L.), were grown for eight years in a NTS.

The experimental design was a randomized complete block with three treatments and four replicates. The treatments consisted of three cropping systems for silage production: monocropped corn, corn intercropped with palisade grass, and corn intercropped with guinea grass. Center-pivot sprinkler irrigation was used, considering the ideal limiting water range for the crops being studied (Doorenbos \& Pruitt, 1977).

The corn was sown at two different sites, with the same soil type and management history, during the 2010-2011 and 2011-2012 growing seasons. The corn crop plots were sown in each replicate adopting the same practices, and each plot consisted of four corn rows that were $20 \mathrm{~m}$ long and $0.90 \mathrm{~m}$ apart, covering a total area of $72 \mathrm{~m}^{2}$. The two central rows were considered as the usable area, and the $0.5 \mathrm{~m}$ at the ends of each plant row and the two external rows were considered as the edges.

On $11 / 22 / 2010$, the plants and weeds in the area were eliminated by applying $1.44 \mathrm{~g} \mathrm{ha}^{-1}$ acidequivalent of glyphosate [isopropylamine salt of $\mathrm{N}$-(phosphonomethyl) glycine] at a spray volume of $200 \mathrm{~L} \mathrm{ha}^{-1}$. Then, on 11/26/2010, the plants were cut using a plant residue crusher.

In the first growing season, the corn triple hybrid BG7049 was sown on $12 / 2 / 2010$, for silage production. In the second growing season, the simple hybrid AG 8088 YG was sown on $12 / 10 / 2011$. The same management plan was adopted both in 2010-2011 and 2011-2012. The corn was sown at a depth of $0.05 \mathrm{~m}$ using a no-tillage drill, at a density of 60,000 seeds per hectare and at a row spacing of $0.90 \mathrm{~m}$. For all treatments and during the two growing seasons, the basic fertilization in the sowing furrows consisted of: $20 \mathrm{~kg} \mathrm{ha}^{-1} \mathrm{~N}, 70 \mathrm{~kg} \mathrm{ha}^{-1} \mathrm{P}_{2} \mathrm{O}_{5}$, and $40 \mathrm{~kg} \mathrm{ha}^{-1} \mathrm{~K}_{2} \mathrm{O}$ using the formulation $08-28-16$.

In the intercropping treatments, the grasses were sown both simultaneously to each other at a density of $7 \mathrm{~kg} \mathrm{ha}^{-1}$ (pure live seed $=76$ and $72 \%$ for palisade grass and guinea grass, respectively) and simultaneously

Table 1. Monthly rainfall, mean maximum and minimum temperatures, and photoperiod during the 2010-2011 and 2011-2012 growing seasons in the municipality of Selvíria, in the state of Mato Grosso do Sul, Brazil.

\begin{tabular}{|c|c|c|c|c|c|c|c|c|c|c|c|c|}
\hline \multirow[t]{2}{*}{ Climate characteristics } & \multicolumn{12}{|c|}{ Month } \\
\hline & Nov. & Dec. & Jan. & Feb. & Mar. & Apr. & May & June & July & Aug. & Sept. & Oct. \\
\hline & \multicolumn{12}{|c|}{ 2010-2011 growing season } \\
\hline Monthly rainfall (mm) & 214 & 288 & 202 & 230 & 356 & 157 & 9 & 41 & 0 & 0 & 3 & 137 \\
\hline Mean maximum temperature $\left({ }^{\circ} \mathrm{C}\right)$ & 31.7 & 31.7 & 32.2 & 31.9 & 30.0 & 31.3 & 28.7 & 27.8 & 30.4 & 31.8 & 34.3 & 32.3 \\
\hline Mean minimum temperature $\left({ }^{\circ} \mathrm{C}\right)$ & 19.5 & 21.4 & 21.3 & 21.2 & 20.7 & 18.7 & 15.8 & 14.1 & 16.0 & 16.7 & 18.5 & 20.8 \\
\hline \multirow[t]{2}{*}{ Photoperiod (hour per day) } & 12.9 & 13.2 & 13.1 & 12.7 & 12.1 & 11.5 & 11.0 & 10.8 & 10.9 & 11.4 & 11.9 & 12.5 \\
\hline & \multicolumn{12}{|c|}{ 2011-2012 growing season } \\
\hline Monthly rainfall (mm) & 123 & 103 & 330 & 123 & 89 & 69 & 34 & 60 & 8 & 0 & 50 & 17 \\
\hline Mean maximum temperature $\left({ }^{\circ} \mathrm{C}\right)$ & 32.0 & 33.6 & 31.2 & 33.0 & 33.1 & 32.0 & 28.0 & 27.8 & 28.2 & 30.9 & 33.6 & 34.9 \\
\hline Mean minimum temperature $\left({ }^{\circ} \mathrm{C}\right)$ & 20.0 & 21.8 & 20.2 & 20.4 & 20.2 & 19.8 & 17.1 & 16.9 & 13.2 & 16.7 & 18.2 & 21.2 \\
\hline Photoperiod (hour per day) & 12.9 & 13.2 & 13.1 & 12.7 & 12.1 & 11.5 & 11.0 & 10.8 & 10.9 & 11.4 & 11.9 & 12.5 \\
\hline
\end{tabular}


to corn in alternate rows, at a depth of $0.08 \mathrm{~m}$ below soil surface, using a no-tillage drill at a row spacing of $0.34 \mathrm{~m}$ (Costa et al., 2012). This method was used to delay the emergence of grasses in relation to the grain-producing crops and to decrease the competition between the species during the initial development period.

For pest control, the corn seeds were treated with insecticides (150 $\mathrm{g} \mathrm{L}^{-1}$ a.i. imidacloprid $+450 \mathrm{~g} \mathrm{~L}^{-1}$ thiodicarb) just before sowing, in order to control the leafhoppers and caterpillars present in the soil. Afterwards, corn and grasses were treated with insecticides (129 $\mathrm{g}^{-1}$ methomyl $+24 \mathrm{~g} \mathrm{ha}^{-1}$ triflumuron) for the control of Spodoptera frugiperda, on $12 / 30 / 2010$ and $1 / 6 / 2011$, during the first growing season, and on $1 / 14 / 2012$, during the second growing season, using $12-\mathrm{m}$-long spray bars spaced at $0.50 \mathrm{~m}$, at a spray volume of $200 \mathrm{~L} \mathrm{ha}^{-1}$.

Topdressing mineral fertilization was applied between corn rows without incorporation $\left(90 \mathrm{~kg} \mathrm{ha}^{-1} \mathrm{~N}\right.$ as urea) during both growing seasons, when the corn plants had six expanded leaves. Later, the experimental area was irrigated with $15 \mathrm{~mm}$ of water to minimize nitrogen losses due to volatilization.

When the corn grains reached the 1/4-milk stage (grains with 34-35\% moisture) on 3/19/2011 and $3 / 25 / 2012$, the crops in each plot were harvested using a mechanical silage forage harvester with 12 knives (model JF-90, JF Máquinas Agrícolas, Itapira, SP, Brazil). The crops were chopped into particles with an average size of $2.5 \mathrm{~cm}$. A pull-type forage harvester was used to harvest the plant mass for ensiling. The cutting height of the species for silage was approximately $0.30 \mathrm{~m}$ above ground surface. This harvest height aims to increase the percentage of grain in the silage mass, to avoid harming the tillering of the grasses in intercropping, and also allows decreasing the amount of stems and senescent leaves in the silage, resulting in better nutritive value.

During both growing seasons, the material was collected and appropriately compacted for storage by pressing (in an adapted hydraulic press) into plastic buckets (one per plot) that were capable of holding $15 \mathrm{~kg}$ of green matter at a density of $600 \mathrm{~kg} \mathrm{~m}^{-3}$ (green mass). The flanges were fitted against the silicon of the laboratory silos to allow gas flow using Bunsen valves, and sand was placed at the bottom to recover the effluent. After filling, the buckets were hermetically sealed using adhesive tape to prevent air exchange with the environment. The silos were opened after having been sealed for 60 days.

At the corn phenological stage, the crops were harvested from the usable areas in each plot using a mechanical harvester. Before harvesting, the final plant population (PP) and the final number of ears (NE), i.e., the number of plants and ears in the usable area extrapolated to plants and ears per hectare, were evaluated. Ten randomly selected plants were chosen to measure plant height $(\mathrm{PH})$ and height of ear insertion (HEI), which were assessed using a centimetergraduated ruler. In addition, the mean diameter of stems (BDS) was determined using a caliper ruler.

Monocropped corn and intercropped plants (corn, palisade grass, and guinea grass) were harvested at a height of $0.30 \mathrm{~m}$ above ground surface. A representative sample was dried using forced-air circulation at $65^{\circ} \mathrm{C}$ for 72 hours, in order to determine forage dry matter yield, which was extrapolated to $\mathrm{Mgha}^{-1}$.

In both the monocropped and intercropped treatments, the species were separated in order to determine the dry mass productivity of corn, palisade grass, and guinea grass. The leaf, stalk, sheath, and panicle fractions of the corn were separated using pruning shears, and the ears were manually separated into the grain, bract (husk), and cob fractions. Subsequently, the samples of each fraction were weighed and placed in a forced-air circulation oven at $65^{\circ} \mathrm{C}$ for 72 hours to dry, in order to determine the contributions of each fraction to the final composition of the ensiled forage mass.

When the material was ensiled, four samples were randomly collected from each plot to obtain the total dry matter (DM) percentage, and four samples were frozen in plastic bags for later laboratory analyses. The crude protein (CP), neutral detergent fiber (NDF), acid detergent fiber (ADF), lignin (LIG), cellulose (CEL), hemicellulose (HCEL), ash, and water-soluble carbohydrate (WSC) contents, as well as buffering capacity (BC), were determined according to the methods described by Silva \& Queiroz (2001) and Playne \& McDonald (1966). The samples were dried at $65^{\circ} \mathrm{C}$ for 72 hours until constant weight. From these measurements, the fermentative capacity (FC) of the materials to be ensiled was calculated according to the following equation, which was proposed by Kaiser et al. (2002): $\mathrm{FC}=\mathrm{DM}+8 \times(\mathrm{WSC} / \mathrm{BC})$, in which 
$\mathrm{DM}$ is expressed as the percentage of WSC, and $\mathrm{BC}$ is expressed as $\mathrm{mEq} \mathrm{HCl} / 100 \mathrm{~g} \mathrm{DM}$.

When the silos were opened on 5/27/2011 and $5 / 12 / 2012$, in order to determine the DM content, four samples were collected and frozen in plastic bags for later laboratory analyses. The DM, CP, ash, ether extract (EE), NDF, ADF, HCEL, CEL, LIG, WSC, neutral detergent insoluble nitrogen (NDIN), acid detergent insoluble nitrogen (ADIN), total carbohydrates (TCs), and in vitro digestible dry matter (IVDDM) contents were obtained as in Silva \& Queiroz (2001). The ratio of ammoniacal nitrogen to total nitrogen $\left(\mathrm{N}-\mathrm{NH}_{3} / \mathrm{TN}\right)$ and $\mathrm{pH}$ were determined using a digital potentiometer to measure the contents of the silage juice that was obtained by pressing (Cunniff, 1995). The total digestible nutrient (TDN) content was determined using the methodology described by the National Research Council (NRC, 2007).

In the intercropping systems, the forage DM yield (FDMY) of palisade and guinea grasses was evaluated at 50 (first cut), 100 (second cut), and 150 (third cut) days after corn silage was harvested. All plants, mainly leaves, at $0.30 \mathrm{~m}$ from soil surface, within a $2-\mathrm{m}^{2}$ area per plot, were cut using manual mechanical rotary mowers. The collected material was dried by forced-air circulation at $65^{\circ} \mathrm{C}$ for 72 hours. The DM was weighed, and the data were extrapolated to $\mathrm{Mg}$ $\mathrm{ha}^{-1}$. Subsamples of palisade grass and guinea grass DM were used to determine the CP and NDF contents (Silva \& Queiroz, 2001).

All data were initially tested for normality with the Shapiro-Wilk test (Shapiro \& Wilk, 1965) using the Univariate procedure of SAS (SAS Institute Inc., Cary, NC, USA), and the results showed that all data were distributed normally ( $\mathrm{W}>0.80$ ). The data for all variables were analyzed with the Proc Mixed procedure of SAS (SAS Institute Inc., Cary, NC, USA), and the Satterthwaite approximation was used to determine the denominator's degrees of freedom for the tests of fixed effects. The cropping system was considered as the fixed effects, and the replicate (block), year, and block (cropping system) as random variables. The model statement used to analyze forage production and the composition of the variables contained the effects of the cropping system. The specified term for the repeated statement was the cut; the subject was the replicate (block $\times$ cropping system); and an autoregressive covariance structure was used for all repeated statements, providing the best fit for these analyses according to Akaike's information criterion. The results were reported as least square means and were separated using the probability of differences (PDIFF) option. The effects were considered to be statistically significant at $5 \%$ probability.

\section{Results and Discussion}

The emergence of corn seedlings occurred five to six days after sowing, which was carried out on 12/7/2010 and 12/16/2011, in the first and second growing seasons, respectively. Grass seedlings emerged 10 and 12 days after sowing, on 12/12/2010 and 12/22/2011, in the first and second growing seasons, respectively. The average periods of corn growth from emergence to grains with $33-34 \%$ moisture, during the first and second growing seasons, were of 102 and 100 days, respectively.

In all cropping systems, high DM yields were found for silage production (Table 2), whereas the greatest corn forage DM yield (36.6 Mg ha' $\mathrm{M}^{-1}$ ) was obtained for the monocropped corn treatment. The mean values of the corn plant components in the silage, including stalks + sheaths + panicles $(29.9 \%)$, leaves $(13.7 \%)$, and bracts $(8.5 \%)$, differed between the cropping systems and were the highest for monocropped corn.

The absence of significant differences between the cropping systems regarding the corn production components (PH, HEI, BDS, PP, and NE) and TDMY showed that the tropical perennial grasses grown in well-managed intercropping systems did not affect the development of the corn crop (Table 2). This may be explained by the fact that corn is considered a strong competitor with smaller plants, such as palisade and guinea grasses (Crusciol et al., 2010). Other studies have also shown the effects of low competition in intercropping systems (Leonel et al., 2009; Costa et al., 2012; Borghi et al., 2013; Crusciol et al., 2013).

In general, the values for the corn production components (PH, HEI, BDS, PP, and NE) obtained in the present study are consistent with those of many others conducted in different farm regions and cropping systems (Leonel et al., 2009; Costa et al., 2012; Borghi et al., 2013; Crusciol et al., 2013; Janusckiewicz et al., 2015).

Intercropping systems may result in lower DM yields of corn forage; however, they establish 
pastures in the off-season, which does not occur in monocropping systems (Figure 1). Those systems can provide feed for animals after the material is harvested for silage or straw, maintaining the continuity of the NTS. However, it should be noted that, compared with palisade grass, which has a caespitose growth habit, guinea grass has more erect tillers and longer and wider leaves throughout the growth period. Therefore, the latter species should be handled correctly, so that it does not form tussocks and compromise the sowing of the crop in succession, on its straw.

Paziani et al. (2009) obtained DM yields between 14.3 and $25.1 \mathrm{Mg} \mathrm{ha}^{-1}$ while evaluating 24 corn cultivars in four regions of Brazil, whereas Skonieski et al. (2014) observed DM yields of 14.8 to $16.8 \mathrm{Mg} \mathrm{ha}^{-1}$ when corn was grown in different spatial arrangements. However, these researches on corn silage production only considered monoculture crops. Leonel et al. (2009) evaluated different cropping systems of corn sown with palisade grass (monocropped corn, monocropped palisade grass, two rows of palisade grass in the corn rows, and palisade grass seeded by throwing over the corn rows) and verified a productivity of corn forage for silage of approximately $17 \mathrm{Mg} \mathrm{ha}^{-1}$.

The DM yields of corn forage obtained in the present study, of 26.6 to $36.6 \mathrm{Mg} \mathrm{ha}^{-1}$ (Table 2), were generally high, regardless of the cropping system. Therefore, the corn that was intended for silage showed good productivity even when it was intercropped with grasses. These findings are important because high TDMYs can dilute the costs of silage production (Costa et al., 2015a), which was shown to be feasible in tropical regions.
Knowledge of the plant composition in terms of stems, leaves, cobs (grain/cobs), and straw is also important for the production of silage. In intercropping systems, grass inclusion in the silage composition is inevitable. In the present study, palisade and guinea grasses in intercropping benefitted from the greater spacing of $0.90 \mathrm{~m}$ between the lines used for the corn crop, due to the increased amount of light that reaches the grasses, which results in greater growth during the plant development period.

Overall, intercropping does not affect the morphological characteristics of the corn crop (Janusckiewicz et al., 2015). According to this author, the morphological components of corn did not differ significantly between treatments, with average values of leaves, stems, ears, and straw of 17.54, 35.19, 33.77, and $13.49 \%$, respectively. Despite the significant differences between some of the morphological characteristics of corn - percentages of stalks + sheaths + panicles, leaves, and bracts - in the present study (Table 2), these only differed slightly between the cropping systems, which shows the viability of intercropped crops in tropical regions. The values found in the present study are similar to those reported by several authors (Zopollatto et al., 2009; Skonieski et al., 2014).

The obtained results show that grasses in intercropping systems have a tendency to decrease corn silage yield, but did not negatively affect the production components and morphological characteristics of the corn crop (Table 2). The intercropping systems for silage production can be important for tropical regions, mainly during the dry season, because silage

Table 2. Plant height (PH), height of ear insertion (HEI), mean baseline diameter of stems (BDS), plant population (PP), number of ears per hectare (NE), total dry matter yield (TDMY) of silage (corn + palisade grass or guinea grass), corn forage dry matter yield (CDMY), forage dry matter yield (FDMY), as well as the percentages of forage species (FE), corn stalks + sheaths + panicles (S+S+P), leaves (L), grains (G), bracts (B), and cobs (C) in the final composition of the ensiled materials from monocropped corn (Zea mays) and corn intercropped with palisade grass (Urochloa brizantha 'Marandu') or guinea grass (Megathyrsus maximus 'Tanzânia') ${ }^{(1)}$.

\begin{tabular}{|c|c|c|c|c|c|c|c|c|c|c|c|c|c|c|}
\hline $\begin{array}{l}\text { Cropping } \\
\text { system }^{(2)}\end{array}$ & $\begin{array}{l}\mathrm{PH} \\
(\mathrm{m})\end{array}$ & $\begin{array}{l}\text { HEI } \\
(\mathrm{m})\end{array}$ & $\begin{array}{l}\text { BDS } \\
(\mathrm{mm})\end{array}$ & $\begin{array}{c}\text { PP } \\
(\text { No. } \times 1,000)\end{array}$ & $\mathrm{NE}$ & $\begin{array}{l}\text { TDMY } \\
--(M \\
\end{array}$ & $\begin{array}{l}\text { CDMY } \\
\left.\mathrm{ha}^{-1}\right)-\end{array}$ & FDMY & FE & $\mathrm{S}+\mathrm{S}+\mathrm{P}$ & L & $\mathrm{G}$ & B & C \\
\hline MC corn & $2.49 \mathrm{a}$ & $1.29 \mathrm{a}$ & $21.2 \mathrm{a}$ & $61.1 \mathrm{a}$ & $63.9 \mathrm{a}$ & $36.6 \mathrm{a}$ & $36.6 \mathrm{a}$ & - & - & $29.9 a$ & $13.7 \mathrm{a}$ & $41.1 \mathrm{a}$ & $8.5 \mathrm{a}$ & $6.7 \mathrm{a}$ \\
\hline Corn + PG & $2.38 \mathrm{a}$ & $1.25 \mathrm{a}$ & $19.4 \mathrm{a}$ & $58.1 \mathrm{a}$ & $61.4 \mathrm{a}$ & $29.9 a$ & $26.2 b$ & $3.7 \mathrm{a}$ & $12.7 \mathrm{a}$ & $24.5 b$ & $11.8 \mathrm{~b}$ & $36.8 \mathrm{a}$ & $7.7 b$ & $6.5 \mathrm{a}$ \\
\hline Corn + GG & $2.46 \mathrm{a}$ & $1.28 \mathrm{a}$ & $20.0 \mathrm{a}$ & $58.4 \mathrm{a}$ & $62.5 \mathrm{a}$ & $32.4 \mathrm{a}$ & $28.7 b$ & $3.7 \mathrm{a}$ & $11.7 \mathrm{a}$ & $23.7 b$ & $13.4 \mathrm{a}$ & $37.9 \mathrm{a}$ & $7.6 \mathrm{~b}$ & $5.7 \mathrm{a}$ \\
\hline $\mathrm{SEM}^{(3)}$ & 0.05 & 0.04 & 0.99 & 1.73 & 2.14 & 2.73 & 2.71 & 4.3 & 1.38 & 1.74 & 0.94 & 1.46 & 0.28 & 0.03 \\
\hline P-value & 0.091 & 0.718 & 0.234 & 0.184 & 0.523 & 0.066 & 0.003 & $<0.001$ & $<0.001$ & 0.004 & 0.159 & 0.021 & 0.008 & 0.012 \\
\hline
\end{tabular}

${ }^{(1)}$ Values followed by equal letters do not differ significantly, at $5 \%$ probability, according to the LSmean and were separated using the probability of differences (PDIFF) option. ${ }^{(2)} \mathrm{MC}$, monocropped; PG, palisade grass; GG, guinea grass. ${ }^{(3)}$ SEM, standard error of the mean. 
provides quality feed for animals and the pasture can supplement low fodder production in the off-season.

Significant differences in the nutritive values between the cropping systems were observed for the materials before ensiling (Table 3). Monocropped corn showed the lowest values of ADF $(24.2 \% \mathrm{DM})$ and CEL (20.4\% DM) and the highest value of FC (36.1\%).

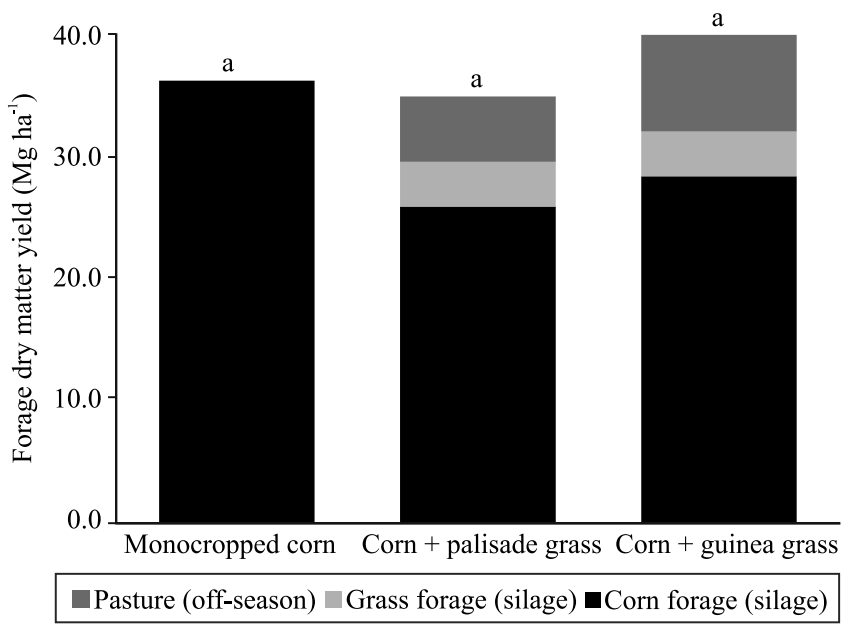

Figure 1. Mean forage dry matter yield of monocropped corn (Zea mays) forage (silage) and of corn + palisade (Urochloa brizantha 'Marandu') or guinea (Megathyrsus maximus 'Tanzânia') grass forage (silage) + pasture (offseason) after corn silage harvest, in the municipality of Selvíria, in the state of Mato Grosso do Sul, Brazil, during the 2010-2011 and 2011-2012 growing seasons. Values followed by equal letters do not differ significantly, at $5 \%$ probability, by the LSmean and were separated using the probability of differences (PDIFF) option.
The highest values of ADF (30.6\% DM) and CEL $(26.2 \% \mathrm{DM})$ were found in corn + guinea grass, but did not differ significantly from those of corn sown with palisade grass.

Similarly to the material before ensiling, significant differences were also found for the nutritive values of the silage from monocropped corn and from the corn intercropped with palisade grass and guinea grass (Table 4). The NDF (45.6\% DM), ADF (21\% DM), and CEL (17.1\% DM) contents were the lowest and that of EE $(5.4 \% \mathrm{DM})$ the highest in monocropped corn. However, these values did not differ statistically between the intercropping systems, regardless of whether corn was grown with palisade or guinea grass. The corn + palisade grass treatment had the highest value of IVDDM (75.5\% DM).

In general, the grasses in intercropping systems have a tendency to increase the fiber contents (ADF and CEL) in corn-based silage (Tables 3 and 4). The optimal point for ensiling forage occurs when the corn plant reaches 30 to $35 \%$ DM (Khan et al., 2015). This phase coincides with the adequate nutritive value in species such as corn and also with the greatest grain yield, which, coupled with the optimum plant moisture content, may ensure good fermentation in the silo (Van Soest, 1994; Khan et al., 2015). However, by the time that grasses intercropped with corn have reached this point of harvest, much of their nutritive value has already been lost, which can increase the fiber content of the silage (Leonel et al., 2009). In intercropped crops that will be harvested for silage, some grasses will inevitably be included in the ensiled material. However, the degree of grass inclusion varies based

Table 3. Dry matter (DM), crude protein (CP), buffering capacity (BC), neutral detergent fiber (NDF), acid detergent fiber (ADF), lignin (LIG), cellulose (CEL), hemicellulose (HCEL), water-soluble carbohydrates (WSC), ash, and fermentative capacity (FC) of the materials before ensiling from monocropped corn (Zea mays) and corn intercropped with palisade grass (Urochloa brizantha 'Marandu') or guinea grass (Megathyrsus maximus 'Tanzânia')(').

\begin{tabular}{|c|c|c|c|c|c|c|c|c|c|c|c|}
\hline $\begin{array}{l}\text { Cropping } \\
\text { system }\end{array}$ & $\begin{array}{l}\mathrm{DM} \\
(\%) \\
\end{array}$ & CP & $\mathrm{BC}$ & NDF & ADF & $\begin{array}{c}\text { LIG } \\
-(\mathrm{DM} \\
\end{array}$ & CEL & HCEL & WSC & Ash & $\begin{array}{l}\mathrm{FC} \\
(\%) \\
\end{array}$ \\
\hline Monocropped corn & $35.0 \mathrm{a}$ & $6.1 \mathrm{a}$ & $17.8 \mathrm{a}$ & $49.3 \mathrm{a}$ & $24.2 \mathrm{~b}$ & $3.1 \mathrm{a}$ & $20.4 b$ & $25.1 \mathrm{a}$ & $11.4 \mathrm{a}$ & $5.2 \mathrm{a}$ & $36.1 \mathrm{a}$ \\
\hline Corn + palisade grass & $32.8 \mathrm{a}$ & $6.1 \mathrm{a}$ & $17.4 \mathrm{a}$ & $56.0 \mathrm{a}$ & $29.3 \mathrm{a}$ & $3.5 \mathrm{a}$ & $24.8 \mathrm{a}$ & $26.4 \mathrm{a}$ & $10.5 \mathrm{a}$ & $5.5 \mathrm{a}$ & $25.9 b$ \\
\hline Corn + guinea grass & $33.4 \mathrm{a}$ & $6.6 \mathrm{a}$ & $17.5 \mathrm{a}$ & $54.4 \mathrm{a}$ & $30.6 \mathrm{a}$ & $3.9 \mathrm{a}$ & $26.2 \mathrm{a}$ & $22.9 \mathrm{a}$ & $10.5 \mathrm{a}$ & $5.0 \mathrm{a}$ & $26.5 b$ \\
\hline $\mathrm{SEM}^{(2)}$ & 1.74 & 0.28 & 1.46 & 2.83 & 2.19 & 0.38 & 1.74 & 0.93 & 0.94 & 0.51 & 2.62 \\
\hline P-value & 0.453 & 0.109 & 0.131 & 0.101 & 0.040 & 0.128 & 0.022 & 0.004 & 0.580 & 0.616 & $<0.001$ \\
\hline
\end{tabular}

${ }^{(1)}$ Values followed by equal letters do not differ significantly, at 5\% probability, according to the LSmean and were separated using the probability of differences (PDIFF) option. ${ }^{(2)}$ SEM, standard error of the mean. 
on multiple factors, such as crop age, height of harvest, climate, species, and seeding density.

The fibrous fraction of the corn plants (stalks, leaves, and bracts) and of the grass species in the intercropped systems represent more than $60 \%$ of DM production in the silage composition (Table 2). The corn intercropped with guinea grass resulted in the highest ADF $(30.6 \%$ DM) and CEL (26.2\% DM) contents, followed by corn intercropped with palisade grass $(29.3$ and $24.8 \%$ DM, respectively) (Table 3). In the intercropping systems evaluated by Leonel et al. (2009), the grass within the silage also increased the final fiber content.

The FC values were highest in the monocropped corn treatment (36.1\%) (Table 3). According to Woolford (1984), the DM, WSC, BC, and FC values are important for the ensilage potential of a forage plant and for silage quality. The results obtained in the present study agree with the ideal parameters that were given by Van Soest (1994) and Khan et al. (2015).

The NDF (45.6\% DM), ADF (21.0\% DM), and CEL $(17.1 \% \mathrm{DM})$ contents were lower in the silage of monocropped corn (Table 4) and were consistent with the ranges that are suitable for animal consumption (Van Soest, 1994; Khan et al., 2015), including intercropping treatments. According to these authors, fiber is the most widely used variable for predicting the concentration of energy in feed. Moreover, forage species generally contain large amounts of fiber, mainly NDF and ADF.

According to Van Soest (1994), NDF is the most limiting factor for bulk consumption by animals. When the NDF level exceeds $60 \%$, DM is negatively correlated with forage consumption. The ADF content is important for digestibility, since forages with $\mathrm{ADF}$ values of approximately $40 \%$ or more have low energy contents and digestibility (Van Soest, 1994; Khan et al., 2015). In the present study, the results for these parameters are below the limiting levels for animal consumption. Therefore, the produced silage in the intercropping systems is considered to have acceptable quality both in terms of NDF and ADF (Table 3).

The EE $(4.5 \%$ DM) content was higher in monocropped corn, and IVDDM (75.5\% DM) for silage was higher with the corn + palisade grass treatment (Table 4). These values are important for silage quality and animal feed acceptability. Several authors (Van Soest, 1994; Khan et al., 2015) pointed out that these values indicate appropriate levels; therefore, in the present study, all of the analyzed cropping systems can be considered as having good quality (Table 4).

There was a significant difference in the FDMY of the tropical perennial grasses after corn silage was harvested (Table 5). Guinea grass (3.6 Mg ha-1) exhibited higher yields than palisade grass $\left(1.7 \mathrm{Mg} \mathrm{ha}^{-1}\right)$ in the first cut. However, there was no difference in the $\mathrm{CP}$ and NDF contents between the tropical perennial grasses in the study period. The obtained FDMY values show that these pastures have good potential for regrowth and the ability to produce pastures during the off-season (Table 5 and Figure 1).

Several authors (Borghi et al., 2013; Costa et al., 2015a; Janusckiewicz et al., 2015; Crusciol et al., 2016) recommend tropical perennial grasses, such as palisade and guinea grasses, for integrated farming systems and

Table 4. Dry matter (DM), ash, neutral detergent insoluble nitrogen (NDIN), acid detergent insoluble nitrogen (ADIN), neutral detergent fiber (NDF), acid detergent fiber (ADF), lignin (LIG), cellulose (CEL), hemicellulose (HEM), $\mathrm{pH}$, crude protein (CP), ether extract (EE), total carbohydrates (TCs), water-soluble carbohydrates (WSCs), total digestible nutrients

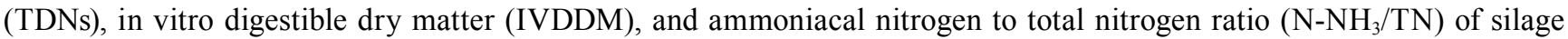
from monocropped corn (Zea mays) and corn intercropped with palisade grass (Urochloa brizantha 'Marandu') or guinea grass (Megathyrsus maximus 'Tanzânia')(1).

\begin{tabular}{lccccccccccccccccccc}
\hline $\begin{array}{l}\text { Cropping } \\
\text { system }^{(2)}\end{array}$ & $\begin{array}{c}\text { DM } \\
(\%)\end{array}$ & Ash & NDIN & ADIN & NDF & ADF & LIG & CEL & HCEL & pH & CP & EE & TCs & WSCs & TDNs IVDDM N-NH \\
\hline MC corn & $36.1 \mathrm{a}$ & $4.4 \mathrm{a}$ & $0.24 \mathrm{a}$ & $0.20 \mathrm{a}$ & $45.6 \mathrm{~b}$ & $21.0 \mathrm{~b}$ & $3.8 \mathrm{a}$ & $17.1 \mathrm{~b}$ & $24.6 \mathrm{a}$ & $3.69 \mathrm{a}$ & $6.5 \mathrm{a}$ & $5.4 \mathrm{a}$ & $84.4 \mathrm{a}$ & $8.7 \mathrm{a}$ & $71.6 \mathrm{a}$ & $69.3 \mathrm{~b}$ & $3.9 \mathrm{a}$ \\
Corn + PG & $33.9 \mathrm{a}$ & $4.8 \mathrm{a}$ & $0.26 \mathrm{a}$ & $0.23 \mathrm{a}$ & $53.1 \mathrm{a}$ & $25.6 \mathrm{a}$ & $3.6 \mathrm{a}$ & $21.9 \mathrm{a}$ & $27.4 \mathrm{a}$ & $3.65 \mathrm{a}$ & $6.0 \mathrm{a}$ & $4.0 \mathrm{~b}$ & $85.8 \mathrm{a}$ & $9.4 \mathrm{a}$ & $71.5 \mathrm{a}$ & $75.5 \mathrm{a}$ & $4.4 \mathrm{a}$ & & \\
Corn + GG & $34.7 \mathrm{a}$ & $5.3 \mathrm{a}$ & $0.27 \mathrm{a}$ & $0.23 \mathrm{a}$ & $52.1 \mathrm{a}$ & $27.7 \mathrm{a}$ & $3.7 \mathrm{a}$ & $23.7 \mathrm{a}$ & $24.4 \mathrm{a}$ & $3.69 \mathrm{a}$ & $6.5 \mathrm{a}$ & $4.0 \mathrm{~b}$ & $85.0 \mathrm{a}$ & $9.6 \mathrm{a}$ & $70.9 \mathrm{a}$ & $69.1 \mathrm{~b}$ & $4.5 \mathrm{a}$ \\
\hline SEM $^{(3)}$ & 1.08 & 0.31 & 0.02 & 0.019 & 1.45 & 1.30 & 0.40 & 1.29 & 1.62 & 0.030 & 0.32 & 0.36 & 1.14 & 0.85 & 1.13 & 1.46 & 0.29 \\
P-value & 0.137 & 0.064 & 0.649 & 0.474 & $<0.001$ & $<0.001$ & 0.889 & $<0.001$ & 0.242 & 0.385 & 0.149 & $<0.001$ & 0.490 & 0.606 & 0.813 & 0.003 & 0.179 \\
\hline
\end{tabular}

${ }^{(1)}$ Values followed by equal letters do not differ significantly, at $5 \%$ probability, according to the LSmean and were separated using the probability of differences (PDIFF) option. ${ }^{(2)} \mathrm{MC}$, monocropped; PG, palisade grass; GG, guinea grass. ${ }^{(3)}$ SEM, standard error of the mean. 
intercropping for sward management. These authors also emphasize that these species are well adapted to Cerrado soils and are excellent alternatives for forage diversification, whereas these systems are excellent options for efficient land use.

It should be highlighted that sowing forage after the cash crop harvest does not provide sufficient fodder during the off-season (Borghi et al., 2013; Crusciol et al., 2013). However, forage production may be increased depending on sowing conditions. In the present study, the forage from the intercropped systems had adequate water availability and was seeded at an appropriate time (at the same time as the corn) and temperature (Borghi et al., 2013). Therefore, intercropping corn with palisade or guinea grass in tropical regions is a good option for the diversification of farm activities, which would allow farmers to use their farm throughout the entire year.

This temporary intercrop can reduce the grassland training costs because the production of corn reduces the costs of seeds and inputs (Costa et al., 2015a). The values of FDMY in the off-season were consistent with those reported in the literature (Borghi et al., 2013; Crusciol et al., 2013, 2016), including nutritive values (Van Soest, 1994).

The results of the present study show the efficiency of intercropping corn with tropical forage species to produce good quality silage (Tables 3 and 4 ) and also to provide pasture in the off-season (Table 5 and Figure 1). However, additional studies should be conducted to better understand the changes that

Table 5. Forage dry matter yield (FDMY), crude protein (CP), and neutral detergent fiber (NDF) contents in palisade grass (Urochloa brizantha 'Marandu') and guinea grass (Megathyrsus maximus 'Tanzânia') pastures at 50 (first cut), 100 (second cut), and 150 (third cut) days in the off-season after corn (Zea mays) silage harvest ${ }^{(1)}$.

\begin{tabular}{|c|c|c|c|c|c|c|c|c|c|}
\hline \multirow[t]{2}{*}{ Treatment } & \multicolumn{3}{|c|}{ FDMY $\left(\mathrm{Mg} \mathrm{ha}^{-1}\right)$} & \multicolumn{3}{|c|}{$\mathrm{CP}(\%)$} & \multicolumn{3}{|c|}{ NDF (\%) } \\
\hline & $1^{\text {st }}$ & $2^{\text {nd }}$ & $3^{\text {rd }}$ & $1^{\text {st }}$ & $2^{\text {nd }}$ & $3^{\text {rd }}$ & $1^{\text {st }}$ & $2^{\text {nd }}$ & $3^{\text {rd }}$ \\
\hline $\mathrm{PG}^{(2)}$ & $1.7 \mathrm{~b}$ & $2.1 \mathrm{a}$ & $1.7 \mathrm{a}$ & $9.3 \mathrm{a}$ & $8.1 \mathrm{a}$ & $6.4 \mathrm{a}$ & $67.7 \mathrm{a}$ & $66.2 \mathrm{a}$ & $69.0 \mathrm{a}$ \\
\hline $\mathrm{GG}^{(2)}$ & $3.6 \mathrm{a}$ & $2.2 \mathrm{a}$ & $2.3 \mathrm{a}$ & $9.0 \mathrm{a}$ & $9.0 \mathrm{a}$ & $7.3 \mathrm{a}$ & $69.3 \mathrm{a}$ & $66.6 \mathrm{a}$ & $65.0 \mathrm{a}$ \\
\hline SEM $^{(3)}$ & 0.3 & 0.3 & 0.3 & 0.9 & 0.9 & 0.9 & 2.1 & 2.1 & 2.1 \\
\hline P-value & $<0.001$ & 0.801 & 0.111 & 0.764 & 0.308 & 0.332 & 0.457 & 0.847 & 0.060 \\
\hline
\end{tabular}

${ }^{(1)}$ Values followed by equal letters do not differ significantly, at $5 \%$ probability, according to the LSmean and were separated using the probability of differences (PDIFF) option. (2) PG, palisade grass; GG, guinea grass. ${ }^{(3)}$ SEM, standard error of the mean. occur in intercropping systems, in order to increase the nutritive quality of silage and pastures. To further establish better agricultural practices, future research should focus on identifying: optimum intercrop species combinations; seeding rates; spatial arrangements; species competition for water, light, and nutrients; fertilization; and soil nutrient conditions that minimize the competition between crops and maximize yield.

\section{Conclusions}

1. Intercropping corn (Zea mays) with palisade grass (Urochloa brizantha 'Marandu') or guinea grass (Megathyrsus maximus 'Tanzânia') is a viable option for producing large quantities of silage with good nutritive value.

2. The production of the evaluated intercropping systems is as high as that of monocropped corn crops in tropical regions and has the advantage of providing pastures in the off-season.

\section{Acknowledgment}

To Fundação de Amparo à Pesquisa do Estado de São Paulo (Fapesp), for financial support to the first author (process No. 2011/01057-0); and to Conselho Nacional de Desenvolvimento Científico e Tecnológico $(\mathrm{CNPq})$, for an award for excellence in research to the second and third authors.

\section{References}

BELL, L.W.; MOORE, A.D. Integrated crop-livestock systems in Australian agriculture: trends, drivers and implications. Agricultural Systems, v.111, p.1-12, 2012. DOI: 10.1016/j. agsy.2012.04.003.

BERNARDES, T.F.; RÊGO, A.C. Study on the practices of silage production and utilization on Brazilian dairy farms. Journal of Dairy Science, v.97, p.1852-1861, 2014. DOI: 10.3168/jds.20137181.

BORGHI, E.; CRUSCIOL, C.A.C.; MATEUS, G.P.; NASCENTE, A.S.; MARTINS, P.O. Intercropping time of corn and palisadegrass or guineagrass affecting grain yield and forage production. Crop Science, v.53, p.629-636, 2013. DOI: 10.2135/ cropsci2012.08.0469.

COSTA, N.R.; ANDREOTTI, M.; BERGAMASCHINE, A.F.; LOPES, K.S.M.; LIMA, A.E. da S. Custo da produção de silagens em sistemas de integração lavoura-pecuária sob plantio direto. Revista Ceres, v.62, p.9-19, 2015a. DOI: 10.1590/0034737 X201562010002. 
COSTA, N.R.; ANDREOTTI, M.; GAMEIRO, R. de A.; PARIZ, C.M.; BUZETTI, S.; LOPES, K.S.M. Adubação nitrogenada no consórcio de milho com duas espécies de braquiária em sistema plantio direto. Pesquisa Agropecuária Brasileira, v.47, p.10381047, 2012. DOI: 10.1590/S0100-204X2012000800003.

COSTA, N.R.; ANDREOTTI, M.; LOPES, K.S.M.; YOKOBATAKE, K.L.; FERREIRA, J.P.; PARIZ, C.M.; BONINI, C. dos S.B.; LONGHINI, V.Z. Atributos do solo e acúmulo de carbono na integração lavoura-pecuária em sistema plantio direto. Revista Brasileira de Ciência do Solo, v.39, p.852-863, 2015 b. DOI: 10.1590/01000683rbcs20140269.

CRUSCIOL, C.A.C.; MARQUES, R.R.; CARMEIS FILHO, A.C.A.; SORATTO, R.P.; COSTA, C.H.M.; FERRARI NETO, J.; CASTRO, G.S.A.; PARIZ, C.M.; CASTILHOS, A.M. de. Annual crop rotation of tropical pastures with no-till soil as affected by lime surface application. European Journal of Agronomy, v.80, p.88-104, 2016. DOI: 10.1016/j.eja.2016.07.002.

CRUSCIOL, C.A.C.; NASCENTE, A.S.; MATEUS, G.P.; BORGHI, E.; LELES, E.P.; SANTOS, N.C.B. Effect of intercropping on yields of corn with different relative maturities and palisadegrass. Agronomy Journal, v.105, p.599-606, 2013. DOI: 10.2134/agronj2012.0426.

CRUSCIOL, C.A.C.; NASCENTE, A.S.; MATEUS, G.P.; PARIZ, C.M.; MARTINS, P.O.; BORGHI, E. Intercropping soybean and palisade grass for enhanced land use efficiency and revenue in a no till system. European Journal of Agronomy, v.58, p.53-62, 2014. DOI: 10.1016/j.eja.2014.05.001.

CRUSCIOL, C.A.C.; SORATTO, R.P.; BORGHI, E.; MATEUS, G.P. Benefits of integrating crops and tropical pastures as systems of production. Better Crops, v.94, p.14-16, 2010.

CUNNIFF, P. (Ed.). Official methods of analysis. $16^{\text {th }}$ ed. Washington: Association of Official Analytical Chemistry, 1995. $1015 \mathrm{p}$.

DOORENBOS, J.; PRUITT, W.O. Guidelines for predicting crop water requirements. Rome: FAO, 1977. 179p. (FAO Irrigation and Drainage Paper, 24). Available at: $<$ http://www.fao. org/3/a-f2430e.pdf $>$. Accessed on: Dec. 102015.

JANUSCKIEWICZ, E.R.; CHIARELLI, C.B.; CUNHA NETO, D.C.; RAPOSO, E.; RUGGIERI, A.C. How the intercropping between corn and palisade grass cultivars affects forage production and pastures characteristics under grazing. American Journal of Plant Sciences, v.6, p.1475-1482, 2015. DOI: 10.4236/ ajps.2015.69146.

KAISER, E.; WEIB, K.; POLIP, L.V. A new concept for the estimation of the ensiling potential of forages. In: INTERNATIONAL SILAGE CONFERENCE, 13., 2002, Auchincruive. Proceedings... Auchincruive: [s.n.], 2002. p.344358.

KHAN, N.A.; YU, P.; ALI, M.; CONE, J.W.; HENDRIKS, W.H. Nutritive value of maize silage in relation to dairy cow performance and milk quality. Journal of the Science of Food and Agriculture, v.95, p.238-252, 2015. DOI: 10.1002/jsfa.6703.

LEONEL, F. de P.; PEREIRA, J.C.; COSTA, M.G.; DE MARCO JÚNIOR, P.; SILVA, C.J. da; LARA, L.A. Consórcio capimbraquiária e milho: comportamento produtivo das culturas e características nutricionais e qualitativas das silagens. Revista Brasileira de Zootecnia, v.38, p.166-176, 2009. DOI: 10.1590/ S1516-35982009000100021.

LIM, J.M.; NESTOR Jr., K.E.; KUNG Jr., L. The effect of hybrid type and dietary proportions of corn silage on the lactation performance of high-producing dairy cows. Journal of Dairy Science, v.98, p.1195-1203, 2015. DOI: 10.3168/jds.2014-8725.

MATEUS, G.P.; CRUSCIOL, C.A.C.; PARIZ, C.M.; BORGHI, E.; COSTA, C.; MARTELLO, J.M.; FRANZLUEBBERS, A.J.; CASTILHOS, A.M. Sidedress nitrogen application rates to sorghum intercropped with tropical perennial grasses. Agronomy Journal, v.108, p.433-447, 2016. DOI: 10.2134/agronj2015.0236.

MENDONÇA, V.Z. de; MELLO, L.M.M. de; ANDREOTTI, M.; PARIZ, C.M.; YANO, E.H.; PEREIRA, F.C.B.L. Liberação de nutrientes da palhada de forrageiras consorciadas com milho e sucessão com soja. Revista Brasileira de Ciência do Solo, v.39, p.183-193, 2015. DOI: 10.1590/01000683rbcs20150666.

NRC. National Research Council. Nutrient requirements of small ruminants: sheep, goats, cervids, and new world camelids. Washington: National Academy Press, 2007. 362p.

PARIZ, C.M.; COSTA, C.; CRUSCIOL, C.A.C.; MEIRELLES, P.R.L.; CASTILHOS, A.M.; ANDREOTTI, M.; COSTA, N.R.; MARTELLO, J.M.; SOUZA, D.M.; SARTO, J.R.W.; FRANZLUEBBERS, A.J. Production and soil responses to intercropping of forage grasses with corn and soybean silage. Agronomy Journal, v.108, p.2541-2553, 2016. DOI: 10.2134/ agronj2016.02.0082.

PAZIANI, S. de F.; DUARTE, A.P.; NUSSIO, L.G.; GALLO, P.B.; BITTAR, C.M.M.; ZOPOLlATTO, M.; RECO, P.C. Características agronômicas e bromatológicas de híbridos de milho para produção de silagem. Revista Brasileira de Zootecnia, v.38, p.411-417, 2009. DOI: 10.1590/S1516-35982009000300002.

PEREIRA, F.C.B.L.; MELLO, L.M.M. de; PARIZ, C.M.; MENDONÇA, V.Z. de; YANO, E.H.; MIRANDA, E.E.V. de; CRUSCIOL, C.A.C. Autumn maize intercropped with tropical forages: crop residues, nutrient cycling, subsequent soybean and soil quality. Revista Brasileira de Ciência do Solo, v.40, p.e0150003, 2016. DOI: 10.1590/18069657rbcs20150003.

PLAYNE, M.J.; MCDONALD, P. The buffering constituents of herbage and of silage. Journal of the Science of Food and Agriculture, v.17, p.264-268, 1966. DOI: 10.1002/jsfa.2740170609.

RAIJ, B. van; ANDRADE, J.C. de; CANTARELLA, H.; QUAGGIO, J.A. (Ed.). Análise química para avaliação da fertilidade de solos tropicais. Campinas: IAC, 2001. 284p.

SANO, E.E.; ROSA, R.; BRITO, J.L.S.; FERREIRA, L.G. Mapeamento semidetalhado do uso da terra do Bioma Cerrado. Pesquisa Agropecuária Brasileira, v.43, p.153-156, 2008. DOI: 10.1590/S0100-204X2008000100020.

SANTOS, H.G. dos; JACOMINE, P.K.T.; ANJOS, L.H.C. dos; OLIVEIRA, V.A. de; OLIVEIRA, J.B. de; COELHO, M.R.; LUMBRERAS, J.F.; CUNHA, T.J.F. (Ed.). Sistema brasileiro de classificação de solos. 2.ed. Rio de Janeiro: Embrapa Solos, 2006. 306p. 
SHAPIRO, S.S.; WILK, M.B. An analysis of variance test for normality (complete samples). Biometrika, v.52, p.591-611, 1965. DOI: $10.1093 /$ biomet/52.3-4.591.

SILVA, D.J.; QUEIROZ, A.C. de. Análise de alimentos: métodos químicos e biológicos. 3.ed. Viçosa: Ed. da UFV, 2001. 235p.

SKONIESKI, F.R.; NÖRNBERG, J.L.; KESSLER, J.D.; DAVID, D.B. de; AZEVEDO, E.B. de; BRÜNING, G.; PIMENTEL, C.M.M. Corn plant arrangement and its effect on silage quality. Revista Brasileira de Zootecnia, v.43, p.114-119, 2014. DOI: 10.1590/S1516-35982014000300002.
VAN SOEST, P.J. Nutritional ecology of the ruminant. $2^{\text {nd }}$ ed. Ithaca: Cornell University, 1994. 476p.

WOOLFORD, M.K. The silage fermentation. New York: M. Dekker, 1984. (Microbiological Series, v.14).

ZOPOLLATTO, M.; NUSSIO, L.G.; MARI, L.J.; SCHMIDT, P.; DUARTE, A.P.; MOURÃO, G.B. Alterações na composição morfológica em função do estádio de maturação em cultivares de milho para produção de silagem. Revista Brasileira de Zootecnia, v.38, p.452-461, 2009. DOI: 10.1590/S151635982009000300008 .

Received on September 7, 2016 and accepted on October 6, 2016 